\title{
Insights into the Recent Use of Modified Adsorbents in Removing Heavy Metal Ions from Aqueous Solution
}

\author{
Sneha Prabha Mishra 1,*(i) \\ 1 Department of Chemistry, Siksha 'O' Anusandhan (Deemed to Be University), Bhubaneswar, 751 030, India \\ * Correspondence: spm_iter@ rediffmail.com;
}

Scopus Author ID:57211529060

Received: 30.03.2021; Revised: 6.05.2021; Accepted: 10.05.2021; Published: 10.06.2021

\begin{abstract}
Natural water gets contaminated with heavy metal ions because of industrial effluents' discharge into the aquatic environment. As these heavy metal ions cause various health hazards, they should be removed from the aqueous solution. Heavy metal ion concentration in the aqueous solution is very less, so conventional metal removal and recovery processes cannot be applied here. The adsorption method is a great alternative to all these processes as it is a cost-effective and easy method. The use of natural, low-cost materials as adsorbents is eco-friendly also. However, metal uptake capacity of low-cost materials is very less. So, modification is required for low-cost materials to increase their efficiency. In the present review, different modification procedures adopted by different researchers have been discussed. Different low-cost materials used are sawdust, fruit and vegetable wastes, soil, minerals, etc. The modifying agents are heat, acids, bases, and other chemicals. Nevertheless, most of the studies are limited to batch tests only. Future research should be carried out on the extension of batch tests to column study for the large-scale treatment of contaminated water, and the cost of modification procedures and their impact on the environment should also be assessed.
\end{abstract}

Keywords: adsorbent; modification; modifying agents; low-cost materials; batch test; column study.

(C) 2021 by the authors. This article is an open-access article distributed under the terms and conditions of the Creative Commons Attribution (CC BY) license (https://creativecommons.org/licenses/by/4.0/).

\section{Introduction}

Water plays a major role in the survival of our lives. But this important natural resource is getting contaminated due to rapid industrialization and population growth [1]. When industrial wastewater is released into the environment, natural water gets contaminated with heavy metal ions. The wastewater of various industries such as pulp and paper mills, fertilizers, steelworks, metal plating, organic chemicals, aircraft plating, finishing, petroleum refineries, tanning, power plants, etc., contains heavy metal ions. These heavy metals exist as ions like $\mathrm{Cu}(\mathrm{II}), \mathrm{Zn}$ (II), $\mathrm{Hg}$ (II), Cd(II), $\mathrm{Ag}(\mathrm{I}), \mathrm{Pb}(\mathrm{II}), \mathrm{Co}(\mathrm{II}), \mathrm{Ni}(\mathrm{II}), \mathrm{Cr}(\mathrm{III}) / \mathrm{Cr}$ (VI), $\mathrm{Fe}(\mathrm{II}) / \mathrm{Fe}(\mathrm{III})$ in aqueous solution. These heavy metal ions cannot be degraded biologically and accumulate in various organisms through the food chain. These are toxic to living organisms, including human beings, and cause various health disorders like organs/nervous system damage, cancer, etc. [2,3]. The maximum contamination level (MCL) for different heavy metal ions in an aqueous solution has been fixed by the United States Environmental Protection Agency (USEPA) [4].

So, industrial wastewater should be appropriately treated before its release into the aqueous environment. Various treatment options are coagulation, ion-exchange, complexation, foam floatation, chemical precipitation, solvent extraction, electrochemical deposition, etc. For 
the removal of low concentrated metal ions from the aqueous solution, these methods are expensive. So, adsorption technology can be a great alternative to all these methods as it has been proved to be economically favorable, and removal of low concentrated metal ions can also be possible due to its high selectivity and high efficiency [5].

The adsorption process surface of the adsorbent plays a major role in which atoms, ions/molecules known as adsorbate accumulate. The adsorption process is simple, costeffective, and non-toxic. Researchers are also maintaining its popularity by increasing its environmental sustainability by choosing different natural, low-cost materials as adsorbents. Sawdust, pine bark, waste tea, coconut husk, groundnut hull, sugarcane bagasse, cassava peel or cassava roots, cashew nutshell, orange peel, clay, wool, etc., are some examples of natural, low-cost adsorbents [6-9]. However, the metal removal capability of these materials is low. These uptakes can be maximized by performing the processes at optimum conditions. Many researchers have also reported the remarkable improvement of various materials' uptake capacities after modifying their surfaces [10]. Therefore, the present work's main objective is to discuss the mechanism of different surface modification processes, different modification procedures adopted by different researchers, and the improvement in metal uptake capacity of some modified adsorbents when used for heavy metal ions removal.

\section{Mechanism of Modification}

The performance of an adsorbent depends on the physical and chemical properties of its surface. A good adsorbent is characterized by large surface area, minimum volume, high chemical and thermal stability, high mechanical strength, high porosity, small pore diameter. These factors lead to the high adsorption capacity of an adsorbent [11]. Surface modification is an act in which a material's physical, chemical, or biological characteristics are modified from its original form, leading to higher uptake capacity [12]. In modification procedures, surface impurities may be removed, producing physical and chemical changes. After modification of surface charge, surface energy, surface area, roughness, hydrophobicity, and functional groups, reactivity is improved [13]. Modification is mainly carried out by mechanical, thermal, or chemical processes. In the thermal process, porosity is developed, whereas surface area is increased in the chemical process. In the chemical modification process, the use of acid, alkali, or salts are involved and the surface functional groups are introduced or improved. Similarly, in the physical modification process, density and solubility increase. Surface modification can also be carried out using different methods, such as thermochemical or mechanochemical methods [14]. Chemical surface modification is better compared to the physical surface modification process. Because it is less time-consuming, and the material's surface chemistry is also influenced directly [15]. Chemical surface modifications also add some new surface properties [16]. After modification,an inexpensive material can be transformed into a valuable product with high adsorption capacity.

\subsection{Acid modification.}

It is the wet oxidation modification process. Acid modification is carried out using mineral acids and other oxidizing agents like $\mathrm{HCl}, \mathrm{H}_{2} \mathrm{SO}_{4}, \mathrm{HNO}_{3}, \mathrm{H}_{3} \mathrm{PO}_{4}, \mathrm{H}_{2} \mathrm{O}_{2}, \mathrm{HClO}$, etc. [17]. After modification, the adsorbent surface becomes more acidic, and the adsorbent's hydrophilic nature also increases due to the reduction of mineral contents [18]. Acidification increases the polar oxygen-containing functional groups on the surface like carboxyl, quinine, 
hydroxyl, carbonyl, carboxylic anhydride, nitro, and lactone, etc. [19]. It increases the negative charge properties of the adsorbent surface and increases the adsorption of positively charged pollutants. Acid treatment also introduces $\mathrm{H}^{+}$ions on the adsorbent surface. So, there is an increase in the adsorption of negatively charged pollutants [20]. The introduction of $\mathrm{H}_{2} \mathrm{SO}_{4}$, $\mathrm{HNO}_{3}, \mathrm{H}_{3} \mathrm{PO}_{4}$ also increases the functional groups such as $\mathrm{CN}, \mathrm{NO}, \mathrm{S}$, and $\mathrm{P}$ [21]. Treatment of activated carbon by $\mathrm{HCl}$ increases different surface oxygen complexes by which the reduction rate of $\mathrm{Cr}(\mathrm{VI})$ is increased [22]. $\mathrm{HCl}$ treatment of activated carbon also changes the surface morphology of the material by introducing different activating agents. Surface modification of coking coal by $\mathrm{H}_{2} \mathrm{SO}_{4}$ increases surface area, pore-volume, hydrophobic, lipophilic, zeta potential values [23]. After modification with acids, more acidic functional groups are introduced. The rising $\%$ of oxygen is resulted from increasing $\mathrm{O} / \mathrm{C}$ and $\mathrm{H} / \mathrm{C}$ molar ratios after $\mathrm{H}_{2} \mathrm{SO}_{4}$ treatment. When $\mathrm{O} / \mathrm{C}$ and $\mathrm{H} / \mathrm{C}$ ratios increase, there is a decrease in hydrophobicity. After treatment with $\mathrm{HNO}_{3}$, the pore walls are broken, and micropores are expanded into meso and macropores [24]. After acid treatment of brown alga, cylindrical pores are developed on its surface due to the release of trapped gases from the biomass, increasing the adsorption capacity[25]. The effect of organic acids is weaker because of their lower strength.

\subsection{Alkaline modification.}

Alkali treatment means the addition of $\mathrm{NaOH}, \mathrm{KOH}, \mathrm{LiOH}, \mathrm{Na}_{2} \mathrm{SiO}_{3}, \mathrm{Na}_{2} \mathrm{CO}_{3}$, oxides. Alkaline modification is carried out by treating the adsorbent surface by reducing agents also. Due to this alkali treatment non-polar nature on the adsorbent surface is increased [26]. Alkali treatment also introduces a positive charge on the adsorbent surface to increase the adsorption of negatively charged adsorbate [18]. Treatment of $\mathrm{NaOH}$ on activated carbon reduces the functional groups containing oxygen. With the increase of alkali concentration, pore volume and the specific surface area also increase [27].

\subsection{Modification by impregnation and organic solvents.}

Impregnation is another type of adsorbent modification process in which uniform distribution of one type of chemical occurs on the porous adsorbent's internal surface. Metal impregnation is carried out by ferric chloride, zirconium, cerium, carbonates, hydroxides, nitrates, etc. [13]. After impregnation stability and regeneration of the adsorbent increase, the adsorbent's practical utility is also increased. While using $\mathrm{Zr}$ impregnated activated carbon, Rehman et al. observed that after impregnation, there is an increase of thermal stability, porosity and oxygen functionality [18]. Organic solvents like ethanol can also be used for the modification of adsorbent surfaces. They introduce some species onto the adsorbent surface so that their adsorption capacity increases. However, its practical application is limited because of its high cost, unsafe and unstable nature. Organic solvents introduce a large number of functional groups on the adsorbent surface [28].

\subsection{Other modifying agents.}

Apart from acidic and basic modifications of adsorbent surfaces, modifications are also carried out by other chemicals such as neutral solutions $\left(\mathrm{NaCl}, \mathrm{ZnCl}_{2}\right)$, oxidants $\left(\mathrm{KMnO}_{4}\right.$, $\mathrm{H}_{2} \mathrm{O}_{2}$ ). According to Wang et al., when wood biochar is treated with $\mathrm{KMnO}_{4}$, its surface is covered by ultrafine particles of $\mathrm{MnO}_{\mathrm{x}}$ containing more no of oxygen-bearing surface 
functional groups leading to more surface area with much-improved metal uptake capacity towards $\mathrm{Pb}(\mathrm{II}), \mathrm{Cd}(\mathrm{II})$ and $\mathrm{Cu}(\mathrm{II})$ [29].

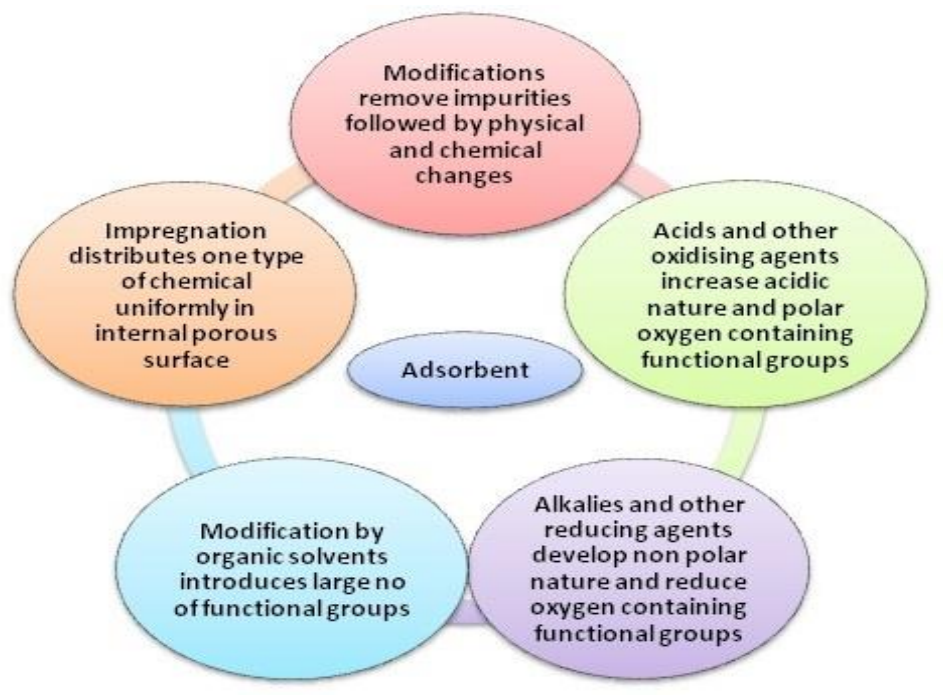

Figure 1. Effect of modifications on the adsorbent.

Different other chemicals have also been used for the modification processes by many researchers, and these are ethanol, acetone, chloroform, $\mathrm{H}_{2} \mathrm{O}_{2}$, polymerization, tetra ethylene glycol, diethyl ether, glycol, $\mathrm{KCl}$, Fenton's reagent, hexadecyl trimethyl ammonium bromide, cetyl pyridinium chloride, n-heptyl benzyl alcohol, halloysite and sepiolite, carbon disulfide, citric acid, peroxy dehydroxide, maleic anhydride, etc. Some of these cases carried out for the removal of heavy metal ions are discussed below.

\section{Use of Modified Adsorbents for Removal of Various Metal Ions}

\section{1. $C d(I I)$.}

Styrofoam waste was treated with sulphuric acid. The sulfonated form of that waste was thus formed for Cd (II) removal from an aqueous solution. The effect of the weight of the waste, sulphuric acid concentration, contact time, and temperature was observed for the sulfonation process, and the maximum sulfonation occurred with $18 \mathrm{M}$ sulphuric acid, $60{ }^{\circ} \mathrm{C}$, $6 \mathrm{~h}$, and $5 \mathrm{~g}$ of styrofoam. The surface properties of the modified adsorbent were studied through SEM, XRD, and FTIR. The adsorption experiments were in batch-wise mode. The sulfonated form of styrofoam obeys the Langmuir isotherm model and pseudo-second-order kinetics. In contrast, unmodified styrofoam follows Freundlich isotherm and intraparticle diffusion mechanism. The Cd(II) uptakes on modified and unmodified forms of styrofoams were 51.6 and $7.09 \mathrm{mg} / \mathrm{g}$, respectively [30]. Argun and Dursun [31] studied the modification of pine bark, a natural adsorbent with Fenton's reagent, and determined its $\mathrm{Cd}$ (II) removal capacity from an aqueous solution. The effect of $\mathrm{Fe}^{2+} / \mathrm{H}_{2} \mathrm{O}_{2}$ ratio, $\mathrm{pH}$, and contact time on adsorption was studied. The reaction follows pseudo-first-order kinetics and Langmuir adsorption isotherm. The Langmuir monolayer adsorption capacity was $30.2 \mathrm{mg} / \mathrm{g}$ at $293 \mathrm{~K}$ temperature. The reaction was also found to be spontaneous and exothermic in natural conditions. The maximum Cd(II) removal (97\%) was achieved at $\mathrm{pH}-7$, contact time - 90 minutes, initial Cd(II) concentration-35 mg/L and solid:liquid ratio - $2.5 \mathrm{~g} / \mathrm{L}$. Dendrocalamus strictus (Bamboo) charcoal was prepared by carbonizing the properly cleaned pieces in a muffle furnace for $2 \mathrm{~h}$ at $450{ }^{\circ} \mathrm{C}$. Then it was cooled, ground and $150 \mu \mathrm{m}$ size was considered 
to be unmodified adsorbent. Some part of this unmodified adsorbent was treated with $1 \%$ nitrilotriacetic acid (NTA) to prepare modified adsorbent, i.e., NTA-modified Dendrocalamus strictus charcoal powder. The surfaces of both modified and unmodified forms of adsorbents were characterized by SEM, XRD, EDX, BET, and CHNS analyzer. Kinetic/isotherm interpretation of the data showed Langmuir and pseudo-second-order isotherm/kinetic models' suitability. Langmuir monolayer adsorption capacities were 142.85 and $166.66 \mathrm{mg} / \mathrm{g}$ for unmodified and modified adsorbents, respectively. Thermodynamic studies showed $\mathrm{Cd}(\mathrm{II})$ adsorption on both modified and unmodified forms of adsorbents to be endothermic and spontaneous. The modified and unmodified adsorbents could be regenerated using $0.5 \%$ calcium chloride and $1 \mathrm{M}$ sulphuric acid [32].

\section{2. $\mathrm{Cu}(I I)$.}

Salihi and his team used raw sugarcane bagasse and microwave incinerated sugarcane bagasse ash (MISCBA) to remove $\mathrm{Cu}$ (II) from aqueous solution and compared the adsorption capacities of both. They found $\mathrm{pH} 6$ and $3 \mathrm{hrs}$ contact time is the optimum conditions for $\mathrm{Cu}$ (II) removal. $\mathrm{Cu}$ (II) uptake capacity of MISCBA was $38.84 \mathrm{mg} / \mathrm{g}$ whereas, that of raw sugarcane bagasse was $9.73 \mathrm{mg} / \mathrm{g}$. Langmuir isotherm obeyed well compared to Freundlich for both the adsorbents [33]. Sabela and his team used activated carbon prepared from vegetable waste for $\mathrm{Cu}$ (II) removal from wastewater. The dried vegetable waste after $\mathrm{KOH}$ treatment for $24 \mathrm{~h}$ was calcined for 10 minutes at $800{ }^{\circ} \mathrm{C}$ temperature. The activated carbon thus prepared was washed with $1 \mathrm{M} \mathrm{HCl}$ to remove excess $\mathrm{KOH}$. The effect of adsorption conditions like $\mathrm{pH}$, adsorbent/adsorbate doses, and contact time were studied in batch adsorption mode. The adsorbent surface was characterized by SEM, TGA, DSC, FTIR, etc. The Langmuir uptake capacity was $75 \mathrm{mg} / \mathrm{g}$ and is equivalent to the $\mathrm{Cu}$ (II) uptake capacity of other reported materials [34]. Saed and Jaleel [35] studied Cu(II) adsorption by using modified and non-modified can papyrus in both batch and continuous flow of adsorption. Can papyrus was modified by urea and thiourea. $\mathrm{Cu}(\mathrm{II})$ removal was $61 \%$ for urea-modified cane, $68 \%$ for thiourea-modified cane compared to $56 \%$ for an unmodified cane. Yeet al. [36] studied the adsorption of $\mathrm{Cu}$ (II) on modified rice husk. The required amount of rice husk was treated with $3 \mathrm{M} \mathrm{NaOH}$ at $60{ }^{\circ} \mathrm{C}$ for $2 \mathrm{~h}$ to remove all silica. Then it was carbonized in the presence of $\mathrm{N}_{2}$ for 45 minutes within the temperature range 400 to $650{ }^{\circ} \mathrm{C}$. The activated carbon thus prepared was used for $\mathrm{Cu}$ (II) removal. The results showed that Langmuir monolayer adsorption capacity on modified rice husk at $\mathrm{pH} 7,25^{\circ} \mathrm{C}$ temperature and initial $\mathrm{Cu}$ (II) concentration $400 \mathrm{mg} / \mathrm{L}$, was $43.5 \mathrm{mg} / \mathrm{g}$. Both Langmuir and Freundlich isotherms suited well.

\section{3. $\mathrm{Cr}(\mathrm{VI})$.}

Banana peels grafted by acrylonitrile (GBPs) were used for $\mathrm{Cr}(\mathrm{VI})$ removal. Banana peels were treated with $10 \% \mathrm{HCl}$ and $10 \% \mathrm{NaOH}$, bleached with sodium chlorate in the presence of $\mathrm{H}_{2} \mathrm{O}_{2}$ and glacial $\mathrm{CH}_{3} \mathrm{COOH}$. Then grafting co-polymerization of this bleached pulp was initiated with acrylonitrile in the presence of Fenton's reagent $\left(\mathrm{Fe}^{+2} / \mathrm{H}_{2} \mathrm{O}_{2}\right)$. The optimum $\mathrm{pH}$ and contact time for $\mathrm{Cr}(\mathrm{VI})$ adsorption on this modified adsorbent were 3 and 120 minutes, respectively. The surface of the adsorbent GBPs was characterized. The adsorption followed both Freundlich and Langmuir isotherms. Langmuir's maximum adsorption capacity on GBPs was found to be $6.2 \mathrm{mg} / \mathrm{g}$. Pseudo-second-order kinetics was obeyed well, and the adsorption was found to be spontaneous and exothermic. GBPs has been proved to be a low- 
cost and efficient adsorbent for removing Cr(VI) [37]. Teff husk-activated carbon was used for $\mathrm{Cr}(\mathrm{VI})$ removal. $95.6 \% \mathrm{Cr}(\mathrm{VI})$ was removed at $1.92 \mathrm{pH}, 87.83 \mathrm{mg} / \mathrm{L}$ initial $\mathrm{Cr}(\mathrm{VI})$ concentration, $2.07 \mathrm{~h}$ contact time and $20.22 \mathrm{~g} / \mathrm{L}$ adsorbent dose. Langmuir isotherm and pseudo-second-order kinetics were obeyed well with Langmuir's maximum uptake capacity of $7.48 \mathrm{mg} / \mathrm{g}$. The authors have planned to extend this small-scale batch adsorption study to a column study [38]. The newspaper waste was separated into pieces and treated with concentrated sodium bicarbonate solution to remove ink, bleaching material, i.e., chlorine dioxide and grease present in the newspaper. It was then refluxed with $5 \% \mathrm{Na}_{2} \mathrm{HPO}_{4}$ for $3 \mathrm{~h}$ using a condenser so that the phosphate's impregnation takes place into the cellulose matrix. After that, the solution was cooled and filtered through Whatman 40 filter paper. The treated waste newspaper (TWNP) was then used for $\mathrm{Cr}(\mathrm{VI})$ removal in batch mode. The optimum contact time was 60 minutes, whereas the optimum $\mathrm{pH}$ was 3. Langmuir isotherm fitted well with maximum Langmuir's uptake capacity of $59.88 \mathrm{mg} / \mathrm{g}$. The said adsorption also obeyed pseudo-second-order kinetics and the rate constants were from 0.0019 to $0.0068 \mathrm{~g} / \mathrm{mg}$.min at an initial $\mathrm{Cr}(\mathrm{VI})$ concentration of $5-20 \mathrm{mg} / \mathrm{L}$ [39].

\section{4. $\operatorname{Co}(I I)$.}

Co(II) from aqueous solution can be removed by chemically modified chitosan, i.e., chitosan vanillin (polymer 1) and chitosan ortho vanillin (polymer 2). At $\mathrm{pH} 4$ and $2 \mathrm{~h}$ of contact time, maximum removal of $\mathrm{Co}$ (II) $(93.2 \%)$ was achieved. Highest $\mathrm{Co}$ (II) uptakes for polymer 1 and 2 were 5.9 and $7.6 \mathrm{mg} / \mathrm{g}$, respectively. The Co(II) uptakes by both of these polymers were spontaneous as well as endothermic in nature. The nature of the interaction between Co(II) and both of these polymers was found to be chemisorption [40]. Coir pith was modified chemically by esterification with succinic anhydride. Then it was activated by $\mathrm{NaHCO}_{3}$ to get a suitable adsorbent for $\mathrm{Co}(\mathrm{II})$ removal. This chemical modification of the adsorbent improved maximum Co(II) loading, indicating more adsorption sites after modification. The adsorbent can be regenerated using $1 \mathrm{~N} \mathrm{HCl}$. The adsorption data followed Langmuir and Freundlich's isotherms both. After modification Co(II) uptake increased from 12.82 to $34.13 \mathrm{mg} / \mathrm{g}$ [41]. The clearing nut (Strychnos potatorum) seed powder is a suitable adsorbent for $\mathrm{Co}(\mathrm{II})$ removal. It possesses $\mathrm{C}-\mathrm{N}, \mathrm{C}-\mathrm{O}$, and - $\mathrm{OH}$ surface functional groups and porous structure. Langmuir's maximum adsorption capacity was found to be $4.25 \mathrm{mg} / \mathrm{g}$. Adsorption of $\mathrm{Co}$ (II) on the said adsorbent was spontaneous and exothermic by nature. From a $20 \mathrm{mg} / \mathrm{L} \mathrm{Co}$ (II) solution, $\mathrm{Co}(\mathrm{II})$ uptake on unmodified and $\mathrm{H}_{2} \mathrm{SO}_{4}$ modified adsorbents CNSP were 1.825 and $2.838 \mathrm{mg} / \mathrm{g}$, respectively [42]. The increase of adsorption capacity on modified adsorbent is due to the reduction of the adsorbent's organic content after acid treatment and more binding sites because of increased porosity.

\section{5. $\mathrm{Ni}(\mathrm{II})$.}

Coconut coir pith modified by $\mathrm{H}_{2} \mathrm{SO}_{4}$ can be a low-cost biosorbent to remove $\mathrm{Ni}$ (II) from an aqueous solution. Different adsorption parameters' effect on the said adsorption was also investigated. The maximum $\mathrm{Ni}$ (II) removal was achieved at $\mathrm{pH}-6.0$, initial $\mathrm{Ni}$ (II) concentration - $50 \mathrm{mg} / \mathrm{L}$, and adsorbent dose $-2.0 \mathrm{~g} / \mathrm{L}$. Adsorption is endothermic. Langmuir isotherm fits well with the adsorption data, and Langmuir's monolayer uptake was $24.39 \mathrm{mg} / \mathrm{g}$. Pseudo-first-order/second-order kinetics and thermodynamic parameters were evaluated [43]. Samarghandi and his team first decolorized sawdust with $1 \%$ formaldehyde, followed by 
activation in a hot air oven for $24 \mathrm{~h}$ at $80{ }^{\circ} \mathrm{C}$. Again the material was reactivated by $\mathrm{H}_{2} \mathrm{SO}_{4}$ for $24 \mathrm{~h}$ at $150{ }^{\circ} \mathrm{C}$, followed by neutralization of the excess acid by $\mathrm{NaHCO}_{3}$. The material thus prepared was dried in an oven for $24 \mathrm{~h}$ at $105{ }^{\circ} \mathrm{C}$ for the preparation of a modified adsorbent for $\mathrm{Ni}$ (II) removal. Maximum $\mathrm{Ni}$ (II) uptake $(22.47 \mathrm{mg} / \mathrm{g}$ ) was achieved at $7 \mathrm{pH}$. The removal efficiency increased with the increase of $\mathrm{pH}$ whereas, it decreased with the $\mathrm{Ni}$ (II) concentration. Langmuir was the better-suited isotherm whereas, pseudo-second-order kinetics obeyed well for the said adsorption [44]. Shah and his group have reviewed Ni(II) adsorption on chemically modified different agricultural wastes. Those are $\mathrm{NaOH}$ modified rice straw, walnut shell, hazelnut shell, peanut hulls, soybean hulls, sawdust, and acid-modified Pouteria sapota seeds, pine sawdust, Ficus religiosa (peepal) leaves, coconut husk, teak tree bark, and many more. Similarly, other modifying agents are ethanol, $\mathrm{H}_{2} \mathrm{O}_{2}$, mercaptoethanoic acid, formaldehyde, $\mathrm{K}_{2} \mathrm{CO}_{3}$, etc. Different other modified agricultural wastes were peat soil, cow dung, digested paddy husk, coir fibers, jute fiber, fluted pumpkin waste, etc. Ni(II) adsorption on all these modified agricultural wastes ranges from 3.37 to $101.01 \mathrm{mg} / \mathrm{g} . \mathrm{K}_{2} \mathrm{CO}_{3}$ modified activated carbon prepared from waste apricot showed this highest Ni(II) uptake [45].

\section{6. $\mathrm{Zn}(I I)$.}

A new low-cost adsorbent Xanthocerassorbifoliabungehull activated carbon (XSBLAC) was prepared by treating Xanthocerassorbifoliabungehull with $\mathrm{H}_{3} \mathrm{PO}_{4}$ followed by carbonization at $500{ }^{\circ} \mathrm{C}$. The adsorbent was characterized based on $\mathrm{N}_{2}$ adsorption-desorption isotherms, XRD, FTIR, SEM, and EDX etc. Langmuir's isotherm and pseudo-second-order kinetics suited well. Langmuir's maximum $\mathrm{Zn}$ (II) uptake was found to be $103.82 \mathrm{mg} / \mathrm{g}$. Entropy, enthalpy, and free energy changes suggested the process to be spontaneous and endothermic. $\mathrm{HNO}_{3}$ was found to be the best desorbing agent for this adsorption [46]. The barley straw, which is a waste of Polish agriculture, has been tried for $\mathrm{Zn}$ (II) removal. For the improvement of $\mathrm{Zn}$ (II) sorption capacity, two modifications have been tried. The first one is the modification by citric acid at a higher temperature, and the other one is the esterification of the straw by methanol. In the citric acid-modified biosorbent, there was an increase in $\mathrm{Zn}$ (II) uptake compared to the unmodified adsorbent. However, with the methanol modified one $\mathrm{Zn}$ (II) sorption was reduced to half of the sorption of that with unmodified sorbent. It was assumed that methanol-modified biosorbent followed an ion-exchange adsorption mechanism where $\mathrm{Ca}^{2+}$ and $\mathrm{Mg}^{2+}$ ions from the straw surface are released into the aqueous solution and compete with $\mathrm{Zn}$ (II) adsorption [47]. The potential application of a low-cost, plentily available agricultural waste Eucalyptus sheathiana bark as adsorbent was tested for $\mathrm{Zn}$ (II) removal. The raw bark, as well as its $\mathrm{NaOH}$ modified form, was tried for $\mathrm{Zn}(\mathrm{II})$ removal. XRD, FTIR, BET, SEM-EDX of both the adsorbents were studied. From the kinetic studies, it has been observed that the process is rapid, multistep, and diffusion controlled in nature. Pseudo-second-order kinetics obeyed well for both the raw and modified adsorbents. Both Freundlich and Langmuir isotherms were obeyed for the modified and unmodified adsorbents. Langmuir's monolayer adsorption capacity on $\mathrm{NaOH}$-treated Eucalyptus sheathiana was $250 \mathrm{mg} / \mathrm{g}$. Different thermodynamic parameters suggested the process to be physical and spontaneous [48]. Microwave incinerated sugarcane bagasse ash (MISCBA) can be used to remove $\mathrm{Zn}$ (II) from wastewater. At low $\mathrm{pH}$, competition between $\mathrm{H}^{+}$and metal ion $\mathrm{Zn}$ (II) arises for the adsorption sites. The optimum $\mathrm{pH}$ for adsorption was 6 , and the optimum contact time was 180 minutes. 
The maximum $\mathrm{Zn}$ (II) uptake was $28.6 \mathrm{mg} / \mathrm{g}$. The $\mathrm{Zn}$ (II) adsorption on MISCBA was found to be multilayer and chemisorptions in nature [49].

\section{7. $P b(I I)$.}

Maize tassel powder was refluxed in a fume cupboard for $4 \mathrm{~h}$ in the presence of $97 \%$ $\mathrm{H}_{2} \mathrm{SO}_{4}$. To neutralize the excess acid, it was treated with $1 \% \mathrm{NaHCO}_{3}$. Then it was washed several times, dried, and kept for use as an adsorbent. Thus, activated carbon prepared from maize tassel has been used for $\mathrm{Pb}$ (II) removal from an aqueous solution by Moyo and his team. The adsorbent surface was characterized, and the effect of different adsorption parameters was studied covering a wide range such as contact time (5 - 300 minutes), $\mathrm{pH}(2-12), \mathrm{Pb}(\mathrm{II})$ concentration $(10-50 \mathrm{mg} / \mathrm{L})$, adsorbent dose $(0.1-2.5 \mathrm{~g})$. The optimum contact time and $\mathrm{pH}$ of adsorption were found to be 60 minutes and 5.4, respectively. Langmuir isotherm fitted better compared to Freundlich isotherm, and Langmuir adsorption capacity was $37.31 \mathrm{mg} / \mathrm{g}$. The adsorbed $\mathrm{Pb}$ (II) can be recovered from the loaded adsorbent by $\mathrm{HCl}$. The authors have expected that the activated carbon prepared from maize tassel can effectively be used for $\mathrm{Pb}$ (II) removal in wastewater treatment plants [50]. Natural zeolite modified by cobalt hexacyanoferrate(III) can be used as an adsorbent for $\mathrm{Pb}$ (II) removal. $\mathrm{Pb}$ (II) uptake was increased 1.8 times after modification. Before modification, it was $60 \mathrm{mg} / \mathrm{g}$, whereas, after modification, it was improved to $100 \mathrm{mg} / \mathrm{g}$ at optimum condition. The optimum contact time for adsorption was $2 \mathrm{~h}$, and the optimum $\mathrm{pH}$ was within the range of 3 to $6 \mathrm{~Pb}$ (II) removal attained a maximum of $90 \%$ at an adsorbent dose of $2 \mathrm{~g} / \mathrm{L}$. The double exponential model explained the sorption kinetics, and the Langmuir model was the best-suited isotherm [51]. Algerian bentonite is a low-cost material, and after modification, it is proved to be a very good $\mathrm{Pb}$ (II) remover from the aqueous solution. The clay was modified with $\mathrm{H}_{2} \mathrm{SO}_{4}, \mathrm{CaCl}_{2}$, and $\mathrm{NaCl}$ separately to get three modified adsorbents, such as acid-activated clay (HC10), calcium homoionic clay (CHC), and sodium homoionic clay (SHC), respectively. As in other adsorption studies, surface properties were evaluated after characterization (BET, XRD, FTIR, and chemical analysis). The effect of different adsorption parameters was also studied. Pseudosecond-order was the better-suited kinetics, and the Langmuir isotherm model fitted best compared to Freundlich and Temkin's model in all the cases. SHC was proved to be the bestmodified clay as the Langmuir maximum uptake capacities were found to be 83.33, 76.9 and $23.8 \mathrm{mg} / \mathrm{g}$ for SHC, CHC, and HC10, respectively. All these adsorbents are more selective towards $\mathrm{Pb}$ (II) compared to $\mathrm{Cu}$ (II) [52].

\subsection{As and $\mathrm{Hg}$.}

Arsenic (As) is considered a human carcinogen (group I) as it is highly toxic and found in soil, rocks, atmosphere, natural water, and organisms. The groundwater of more than 70 countries is contaminated with arsenic. So, As removal from polluted water is a great challenge today, The currently available techniques are costly and require a skilled workforce. So, the adsorption technique using natural, low-cost materials for removal and recovery of As from the aqueous solution has been given more priority. To increase the efficiency, these low-cost materials may be modified chemically. Asere and his coworkers have reviewed the topic "Arsenic removal by chemically modified natural adsorbents". Under these natural materials, rocks, clay, soil, hydroxylapatite and struvite, industrial wastes, biosorbents, and zeolites are included. These are modified either by heat, acid treatment, or by other chemicals. As arsenic 
has a high affinity towards iron and aluminum oxides, natural materials treated with iron or/and aluminum oxide can be a very good adsorbent for As removal. Removing using biosorbents can reduce total treatment costs by more than $20 \%$ compared to other conventional methods. Biosorbents also have low As removal capacity. Chemical modification of biosorbents also increases As removal capacity. Biosorbents like chitosan after chemical treatment show enhanced As removal capacity, and its mechanical strength and acid resistance also increase [53]. Mercury $(\mathrm{Hg})$ is considered to be another most toxic heavy metal like As. Since the conventional treatment technologies are not practically feasible, Attari and his team have tested a low-cost material, i.e., a synthesized zeolite Linde Type A (LTA) from coal fly ash (CFA ZA). $\mathrm{Hg}$ (II) removal on this CFA - ZA was $94 \%$ from a $10 \mathrm{mg} / \mathrm{L} \mathrm{Hg}$ (II) solution, and the result is comparable to that of commercial activated carbon. The equilibrium contact time was 120 minutes, and the adsorption was described well by Freundlich isotherm and pseudo-secondorder kinetics [54].

\subsection{Adsorption of multi-metal ions.}

Two adsorbents, oxidized sugarcane bagasse and oxidized cellulose were prepared by treating sugarcane bagasse and cellulose with $\mathrm{H}_{3} \mathrm{PO}_{4}-\mathrm{NaNO}_{2}$ mixture so that a large number of carboxylic groups are introduced on the adsorbent surface. These adsorbents were used to remove $\mathrm{Cu}$ (II) and $\mathrm{Co}$ (II) from the aqueous solution. Maximum $\mathrm{Co}$ (II) uptake on oxidized cellulose and oxidized sugar cane bagasse were 0.68 and $0.37 \mathrm{~m} \mathrm{~mol} / \mathrm{g}$, respectively, whereas $\mathrm{Cu}$ (II) uptake on the same was 1.20 and $0.57 \mathrm{~m} \mathrm{~mol} / \mathrm{g}$, respectively. Oxidized sugarcane bagasse was proved to be an effective biosorbent for large-scale use [55]. Cassava (Manihotesculenta crantz) roots and cassava peels processing residues were modified by $\mathrm{H}_{2} \mathrm{SO}_{4}, \mathrm{NaOH}$, and $\mathrm{H}_{2} \mathrm{O}_{2}$ to prepare suitable adsorbents for the removal of $\mathrm{Cr}$ (III), $\mathrm{Cd}$ (II), and $\mathrm{Pb}$ (II) from the polluted water. The effect of contact time, $\mathrm{pH}$, adsorbent/adsorbate doses, and temperature were studied. The data were fitted to Freundlich, Langmuir, pseudo-first/secondorder kinetics, and different thermodynamic parameters such as enthalpy, entropy, and free energy changes were calculated. The optimum contact time for removing all the 3 ions by the said adsorbents is 40 minutes. Langmuir isotherm obeyed well, indicating monolayer adsorption in all the cases. Maximum $\mathrm{Cd}(\mathrm{II})$ and $\mathrm{Pb}(\mathrm{II})$ uptake were observed for the $\mathrm{NaOH}$ modified adsorbents and were 19.54 and $42.46 \mathrm{mg} / \mathrm{g}$, respectively, whereas maximum $\mathrm{Cr}$ (III) uptake was observed with $\mathrm{H}_{2} \mathrm{O}_{2}$ modified adsorbent and was found to be $43.97 \mathrm{mg} / \mathrm{g}$. It has been proved to be an efficient, cost-effective, plentily available, and renewable adsorbent to eliminate different metals from industrial wastewater [56]. To eliminate heavy metals from the aqueous solution, a green adsorbent was synthesized by treating glass waste hydrothermally followed by HCl's surface activation. This novel adsorbent was then characterized by BET, $\mathrm{SEM}, \mathrm{XRF}$, and XRD. Removal of $\mathrm{Cu}, \mathrm{Cd}, \mathrm{Zn}, \mathrm{Pb}$, and $\mathrm{Fe}$ was tested with the said adsorbent on batch experiments. The effect of different adsorption parameters, isotherms, and kinetic equations was tested for all the above-mentioned adsorption studies. Langmuir isotherm and pseudo-second-order kinetics were obeyed well in all the cases. 99 - $100 \%$ removal of all the metals occurs at $\mathrm{pH} 7$ and $2 \mathrm{~h}$ of contact time. This adsorption study was applied to healthy water for metal removal [57]. $\mathrm{KCl}$ chemically reactivated agricultural waste-activated carbon. It was then utilized to remove $\mathrm{As}$ (III) and $\mathrm{Pb}$ (II) from aqueous solution in batch methods. Effect of $\mathrm{pH}$, contact time, temperature, and adsorbent/adsorbate doses were determined. The adsorbent surface was characterized based on BET, FTIR, XRD, and SEM-EDX. As(III) and 
$\mathrm{Pb}$ (II) uptakes were 200 and $250 \mathrm{mg} / \mathrm{g}$, respectively. The adsorption data were fitted best with the Langmuir model. Kinetics and thermodynamic studies conclude the process as pseudosecond-order, spontaneous, physical, and exothermic. $\mathrm{As}(\mathrm{III})$ and $\mathrm{Pb}$ (II) uptakes on this agricultural waste composite, activated carbon (AWCAC) was found to be comparable to the other reported adsorbents [58].

Figure 2(a) summarizes the preparation methods of modified adsorbents from different low-cost materials such as agricultural and household wastes, plant and animal wastes, soil, clay, ores, etc. Simple heat/acid/base/chemical treatments are used for modifications. In some cases, heat and chemicals are both used for modifications. Heat is applied first, followed by chemical treatment or vice versa. Figure 2(b) shows that after modifying the adsorbent surfaces, there is an improvement in surface area, adsorption capacity, mechanical strength, and acid resistance power. Before adsorption, the modified adsorbents' surface properties are evaluated by characterizing through XRD, BET, SEM, FTIR, EDX, etc. The adsorption processes for the removal of different metal ions by modified adsorbents in most of the cases are found to be spontaneous; it follows Langmuir isotherm and pseudo-second-order kinetics.

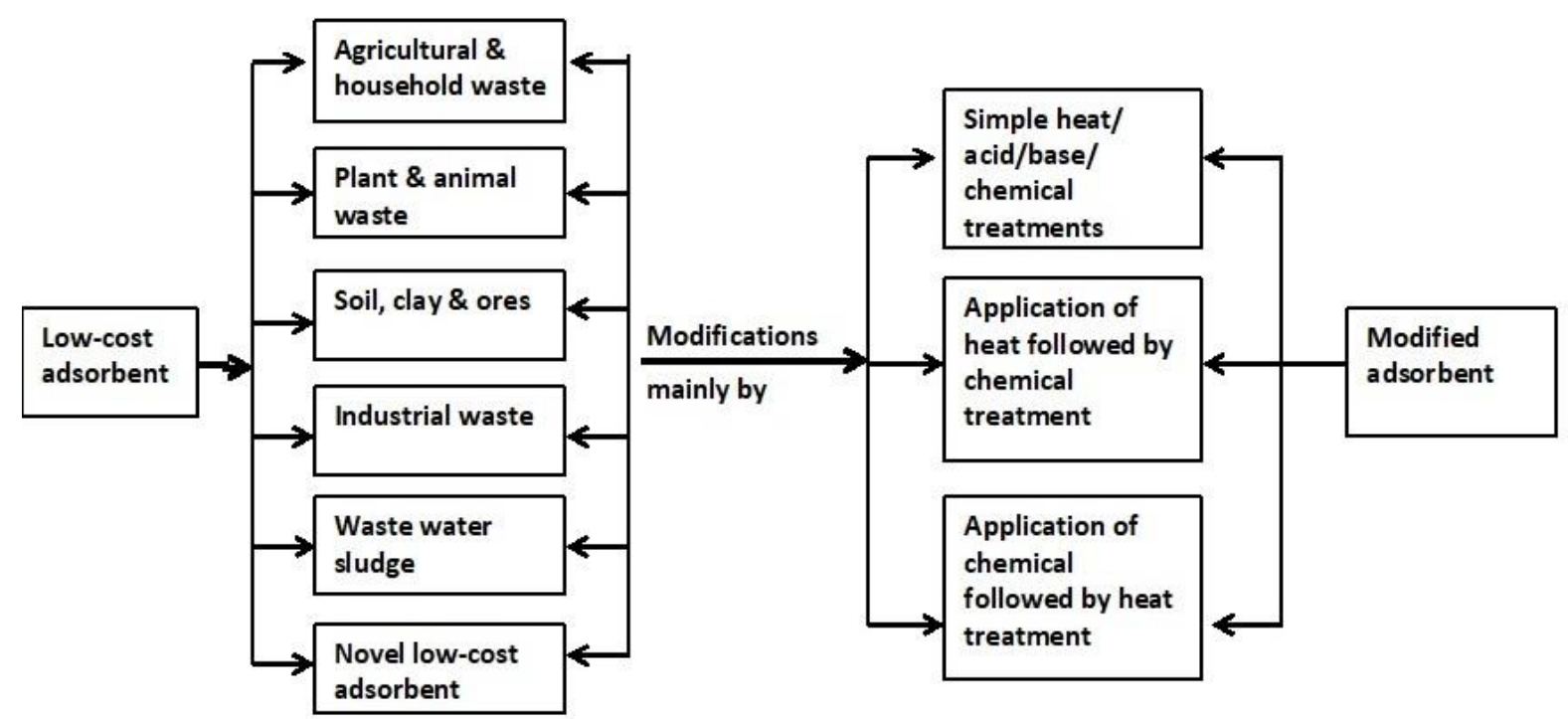

(a)

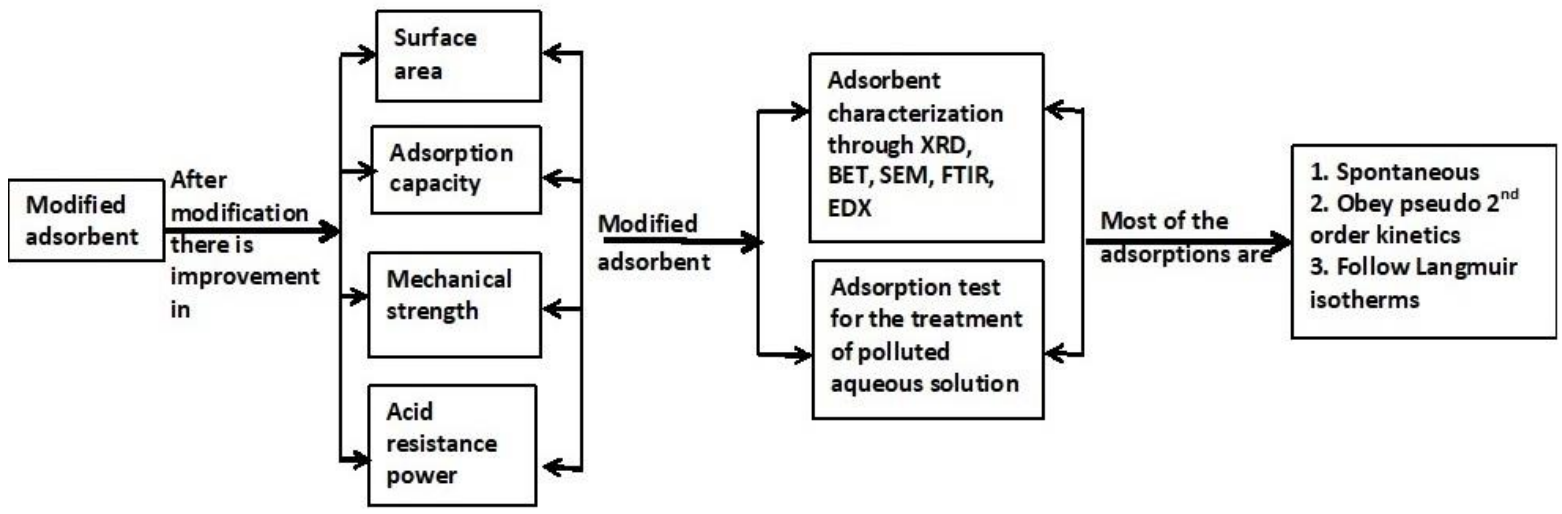

(b)

Figure 2. (a) Preparation methods of modified adsorbents out of different low-cost materials ; (b) Use of modified adsorbents in the adsorption studies.

After modifying the adsorbent, surface properties are developed, thereby increasing their metal uptake capacities. Some examples are highlighted below in Table 1. 
Table 1.Use of some modified adsorbents for heavy metal removal along with their improvement in metal uptake capacities.

\begin{tabular}{|c|c|c|c|c|c|}
\hline $\begin{array}{l}\text { Sl. } \\
\text { No }\end{array}$ & $\begin{array}{l}\text { Low-cost } \\
\text { natural } \\
\text { material }\end{array}$ & Modifying agent & $\begin{array}{l}\text { Metal } \\
\text { contaminants }\end{array}$ & Improvement in metal uptake capacities & References \\
\hline 1 & Wheat straw & Lactic acid & $\mathrm{Pb}(\mathrm{II})$ & $\begin{array}{l}\text { Introduction of } \mathrm{COOH} \text { and } \mathrm{OH} \text { groups after } \\
\text { modification. } 79 \% \text { removal by raw wheat } \\
\text { straw and } 97 \% \text { by modified wheat straw. }\end{array}$ & [59] \\
\hline \multirow[t]{2}{*}{2} & $\begin{array}{l}\text { Agricultural } \\
\text { waste } \\
\text { (Macademia } \\
\text { activated } \\
\text { carbon) }\end{array}$ & (i) $\mathrm{H}_{2} \mathrm{SO}_{4}$ & $\mathrm{Cr}(\mathrm{VI})$ & $\begin{array}{l}\text { (i) Uptake was decreased from } 22.3 \text { to } 9.66 \\
\mathrm{mg} / \mathrm{g} \text { after } \mathrm{H}_{2} \mathrm{SO}_{4} \text { treatment }\end{array}$ & [21] \\
\hline & & (ii) $\mathrm{HNO}_{3}$ & $\mathrm{Cr}(\mathrm{VI})$ & $\begin{array}{l}\text { (ii) Surface area increased from } 545 \text { to } 824 \\
\mathrm{~m}^{2} / \mathrm{g} \text {, and uptake capacity increased from } \\
22.3 \text { to } 40.99 \mathrm{mg} / \mathrm{g}\end{array}$ & \\
\hline 3 & $\begin{array}{l}\text { Activated } \\
\text { carbon fiber }\end{array}$ & $\mathrm{HNO}_{3}$ & As(III) & $\begin{array}{l}\text { Uptake by raw and modified adsorbents was } \\
2.06 \text { to } 2.98 \mathrm{mg} / \mathrm{g} \text {, respectively }\end{array}$ & [60] \\
\hline 4 & Onion skin & $\begin{array}{l}\text { Thiogycolic acid } \\
\text { (organic) }\end{array}$ & $\mathrm{Pb}(\mathrm{II})$ & $\begin{array}{l}\text { Uptake by raw and modified adsorbents were } \\
4.9 \text { to } 6.17 \mathrm{mg} / \mathrm{g} \text { respectively }\end{array}$ & [61] \\
\hline \multirow[t]{2}{*}{5} & $\begin{array}{l}\text { Pisha } \\
\text { sandstone }\end{array}$ & $\mathrm{NaCl}$ & (i) $\mathrm{Cd}$ (II) & $\begin{array}{l}\text { (i) Uptake improved from } 8.2 \text { to } 65.9 \% \text { after } \\
\text { modification }\end{array}$ & [62] \\
\hline & & & (ii) $\mathrm{Cu}(\mathrm{II})$ & $\begin{array}{l}\text { (ii) } \mathrm{Na}^{+} \text {is grafted onto PS after modification } \\
\text { and uptake improved from } 1.3 \text { to } 99.8 \%\end{array}$ & \\
\hline 6 & Rice husk & $\mathrm{NaOH}$ & $\mathrm{Cu}(\mathrm{II})$ & $\begin{array}{l}48.841 \mathrm{mg} / \mathrm{g} \mathrm{Cu}(\mathrm{II}) \text { uptake on the modified } \\
\text { adsorbent. Due to modification, there are an } \\
\text { increase in the intensity of } \mathrm{OH}, \mathrm{CH} \text { and } \mathrm{C}=\mathrm{O} \\
\text { groups, which have high ionic exchange } \\
\text { capacity }\end{array}$ & [63] \\
\hline \multirow[t]{2}{*}{7} & $\begin{array}{l}\text { Saudi clay } \\
\text { (i) Tabbuk } \\
\text { clay }\end{array}$ & $\mathrm{H}_{2} \mathrm{O}_{2}$ & $\mathrm{Co}(\mathrm{II})$ & $\begin{array}{l}\text { BET surface area increased from } 1.478 \text { to } \\
1.488 \mathrm{~m}^{2} / \mathrm{g} \text {, and uptake improved from } 3.94 \\
\text { to } 12.9 \mathrm{mg} / \mathrm{g}\end{array}$ & [64] \\
\hline & $\begin{array}{l}\text { (ii) Bahhah } \\
\text { clay }\end{array}$ & $\mathrm{NaCl}$ & $\mathrm{Co}(\mathrm{II})$ & $\begin{array}{l}\text { BET surface area increased from } 0.3799 \text { to } \\
0.7809 \mathrm{~m}^{2} / \mathrm{g} \text {, and uptake improved from } 3.44 \\
\text { to } 12.55 \mathrm{mg} / \mathrm{g}\end{array}$ & \\
\hline \multirow[t]{2}{*}{8} & $\begin{array}{l}\text { Doum palm } \\
\text { (Hyphaene } \\
\text { thebaica) } \\
\text { seed coats }\end{array}$ & $\begin{array}{l}\text { (i) Physical } \\
\text { activation by } \\
\text { carbonization }(300 \\
\left.{ }^{\circ} \mathrm{C}, 1 \mathrm{~h}\right)\end{array}$ & $\mathrm{Ni}(\mathrm{II})$ & Uptake increases from 3.24 to $4.93 \mathrm{mg} / \mathrm{g}$ & [65] \\
\hline & & $\begin{array}{l}\text { (ii) Soaking it in } \\
28 \% \mathrm{H}_{3} \mathrm{PO}_{4} \text { for } 24 \\
\mathrm{~h} \text { followed by } \\
\text { carbonization in } \\
\text { the absence of air } \\
\left(300^{\circ} \mathrm{C}, 1 \mathrm{~h}\right)\end{array}$ & & Uptake increases from 3.24 to $13.51 \mathrm{mg} / \mathrm{g}$ & \\
\hline \multirow[t]{2}{*}{9} & $\begin{array}{l}\text { Dead } \\
\text { biomass of } \\
\text { brown alga } \\
\text { Sargassum } \\
\text { sp, }\end{array}$ & $0.1 \mathrm{~N} \mathrm{HCl}$ & (i) $\mathrm{Cd}$ (II) & (i) Uptake increases from 2.31 to $2.89 \mathrm{mg} / \mathrm{g}$ & [25] \\
\hline & & & (ii) $\mathrm{Zn}(\mathrm{II})$ & (ii) Uptake increases from 1.39 to $1.85 \mathrm{mg} / \mathrm{g}$ & \\
\hline \multirow[t]{3}{*}{10} & $\begin{array}{l}\text { Sugarcane } \\
\text { bagasse }\end{array}$ & $\begin{array}{l}\text { (i) Heat treatment } \\
\left(550{ }^{\circ} \mathrm{C}, 30 \mathrm{~min}\right)\end{array}$ & $\mathrm{Hg}(\mathrm{II})$ & $\begin{array}{l}\text { (i) BET surface area increases from } 5.21 \text { to } \\
182.69 \mathrm{~m}^{2} / \mathrm{g} \text {, pore volume increases from } \\
0.002 \text { to } 0.081 \mathrm{~cm}^{3} / \mathrm{g} \text {, and removal increases } \\
\text { from } 21 \text { to } 95 \% \text {, }\end{array}$ & [66] \\
\hline & & $\begin{array}{l}\text { (ii) Sugarcane } \\
\text { bagasse treated } \\
\text { with } \mathrm{ZnCl}_{2} \\
\text { followed by heat } \\
\text { activation }\end{array}$ & & $\begin{array}{l}\text { (ii) BET surface area increases from } 5.21 \text { to } \\
182.92 \mathrm{~m}^{2} / \mathrm{g} \text {, pore volume increases from } \\
0.002 \text { to } 0.079 \mathrm{~cm}^{3} / \mathrm{g} \text {, and removal increases } \\
\text { from } 21 \text { to } 85 \% \text {, }\end{array}$ & \\
\hline & & $\begin{array}{l}\text { (ii) Treated with } \\
\mathrm{ZnCl}_{2} \text { followed by } \\
\text { heat activation }\end{array}$ & & $\begin{array}{l}\text { (ii) BET surface area increases from } 5.21 \text { to } \\
7.44 \mathrm{~m}^{2} / \mathrm{g} \text {, pore volume increases from } 0.002 \\
\text { to } 0.013 \mathrm{~cm}^{3} / \mathrm{g} \text {, and removal increases from } \\
21 \text { to } 88 \% \text {, }\end{array}$ & \\
\hline
\end{tabular}




\section{Conclusions and Future Scope}

The use of low-cost materials as adsorbents to eliminate metal ions from the aqueous environment is a cost-effective and eco-friendly method. After heat or, chemical treatments their surface properties are improved, increasing their sorption capacities. Modification of adsorbents increases their metal uptake capacities and increases their mechanical strength and acid resistance power. In almost all adsorption cases studied here, pseudo-second-order kinetics and Langmuir isotherm models were observed well. Thermodynamic studies also showed all the processes to be spontaneous. Till now, the use of modified adsorbents for heavy metal removal is limited to laboratory scale only. Therefore, further research is essential for understanding real adsorption mechanisms. The batch adsorption studies should be shifted to the column to treat real contaminated water on a large scale. Due to these chemical treatment methods, the treatment cost and environment are also affected. So, it is essential to assess the cost of chemical treatment and its environmental effect.

\section{Funding}

This research received no external funding.

\section{Acknowledgments}

The author thanks The President, Siksha 'O' Anusandhan (Deemed to be University), Bhubaneswar, for his kind permission to publish this paper.

\section{Conflicts of Interest}

The author declares no conflict of interest.

\section{References}

1. Masindi, V.; Muedi, K.L. Environmental contamination by heavy metals. ed.; Saleh, H.E.M., Aglan, R.F.; Publisher: IntechOpen, London, 2018. https://doi.org/10.5772/intechopen.76082.

2. Ali, H.; Khan, E.; Ilahi, I. Environmental chemistry and ecotoxicology of hazardous heavy metals: Environmental persistence, toxicity, and bioaccumulation. J. Chem. 2019. https://doi.org/10.1155/2019/6730305.

3. Rai, P.K.; Lee, S.S.; Zhang, M.; Tsang, Y.F.; Kim, K.H. Heavy metals in food crops: Health risks, fate, mechanisms, and management. Environ. Int. 2019, 125, 365-385. https://doi.org/10.1016/j.envint.2019.01.067.

4. Oyem, H.H.; Oyem, I.M.; Usese, A.I. Iron, manganese, cadmium, chromium, zinc and arsenic groundwater contents of Agbor and Owa communities of Nigeria. Springerplus 2015, 4, 104. https://doi.org/10.1186/s40064-015-0867-0.

5. Kristanti, R.A.; Hadibarata, T.; Al Qahtani, H.M.S. Adsorption of bisphenol A on oil palm biomass activated carbon: characterization, isotherm, kinetic and thermodynamic studies. Biointerface Research in Applied Chemistry 2019, 9, 4217-4224. https://doi.org/10.33263/BRIAC95.217224.

6. Bulut, Y; Tez, Z. Removal of heavy metals from aqueous solution by sawdust adsorption.J. of Env. Sciences 2007, 19, 160-166.https://doi.org/10.1016/S1001-0742(07)60026-6.

7. Mnasri-Ghnimi, S.; Frini-Srasra, N. Removal of heavy metals from aqueous solutions by adsorption using $\begin{array}{llllll}\text { single and mixed pillared clays.Applied Clay Science 2019, } & \text { 179, }\end{array}$ 105151.https://doi.org/10.1016/j.clay.2019.105151.

8. Botlagunta, M.; Kamma, S.; Mallampalli, B.; Kambila, V.K. Adsorbent, dielectric and discharge characteristic properties of banana agricultural waste. Biointerface Research in Applied Chemistry 2018, 8 , $3335-3338$. 
9. Çelebi, H.; Gök, G.; Gök, O. Adsorption capability of brewed tea waste in waters containing toxic lead(II), cadmium (II), nickel (II), and zinc(II) heavy metal ions. Sci Rep 2020,10, 17570.https://doi.org/10.1038/s41598-020-74553-4.

10. Manyangadze, M.; Chikuruwo, N.H.M.; Narsaiah, T.B.; Chakra, C.S.; Radhakumari, M.; Danha, G. Enhancing adsorption capacity of nano-adsorbents via surface modification: A review. S. Afr. J. Chem. Eng. 2020, 31, 25-32.https://doi.org/10.1016/j.sajce.2019.11.003.

11. Yakout, S.M. Effect of porosity and surface chemistry on the adsorption-desorption of uranium(VI) from aqueous solution and groundwater.J Radioanal Nucl Chem 2016, 308,555565.https://doi.org/10.1007/s10967-015-4408-7.

12. Bose, S.; Robertson, S.F.; Bandyopadhyay, A. Surface Modification of Biomaterials and Biomedical Devices using Additive Manufacturing. Acta Biomater 2018, 66, 6-22.https://doi.org/10.1016/j.actbio.2017.11.003.

13. Abegunde, S.M., Idowu, K.S.; Adejuwon, O.M.; Adeyemi-Adejolu, T. A review on the influence of chemical modification on the performance of adsorbents. Resources, Environment and Sustainability 2020, 1, 100001.https://doi.org/10.1016/j.resenv.2020.100001.

14. Tole, I.; Habermehl-Cwirzen, K.; Cwirzen, A.Mechanochemical activation of natural clay minerals: An alternative to produce sustainable cementitious binders-review. Mineral. Petrol. 2019, 113, 449462.https://doi.org/10.1007/s00710-019-00666-y.

15. Manory, R.R.Some principles for understanding surface modification of metalsby glow discharge processes. Mater. Manuf. Process 1990, 5, 445-470.https://doi.org/10.1080/10426919008953265.

16. Rostami, E.; Norouzbeigi, R.; Kelishami, A.R.Thermal and chemical modification of bentonite for adsorption of an anionic dye. Adv. Environ. Technol. 2018, 4, 1-12.https://doi.org/10.22104/AET.2018.1844.1088.

17. Mishra S.P. Adsorption-desorption of heavy metal ions. Current Science 2014, 107, 601-612.

18. Rehman, A.; Park, M.; Park, S.J. Current progress on the surface chemical modification of carbonaceous materials. Coatings 2019, 9, 103.https://doi.org/10.3390/coatings9020103.

19. Enaime, G.; Baçaoui, A.; Yaacoubi, A.; Lübken, M. Biochar for wastewater treatment-Conversion technologies and applications. Appl. Sci. 2020, 10, 3492.https://doi.org/10.3390/app10103492.

20. Huang, B.; Liu, G.; Wang, P.; Zhao, X.; Xu, H. Effect of nitric acid modificationon characteristics and adsorption properties of lignite. Processes 2019, 7, 167.http://dx.doi.org/10.3390/pr7030167.

21. Lesaoana, M.; Mlaba, R.P.V.; Mtunzi, F.M.; Klink, M.J.; Ejidike, P.; Pakade, V.E.Influence of inorganic acid modification on $\mathrm{Cr}(\mathrm{VI})$ adsorption performance and thephysicochemical properties of activated carbon. $S$. Afr. J. Chem. Eng. 2019, 28, 8-18.https://doi.org/10.1016/j.sajce.2019.01.001.

22. Park, S.J.; Jang, Y.S.Pore structure and surface properties of chemically modifiedactivated carbons for adsorption mechanism and rate of $\mathrm{Cr}$ (VI). J. Colloid InterfaceSci. 2002, 249, 458463.https://doi.org/10.1006/jcis.2002.8269.

23. Gao, L.; Wen, H.; Tian, Q.; Wang, Y.; Li, G. Influence of surface modification bysulfuric acid on coking coal's adsorption of coking wastewater. Water Sci. Technol. 2017, 76, 555566.https://doi.org/10.2166/wst.2017.219.

24. Godwini, P.M.;Pan, Y.; Xiaoi, H.; Afzal, M.T.Progress in preparation and application of modified biochar for improving heavy metal ion removal from wastewater. Journal of Bioresources and Bioproducts 2019, 4, 31-42, https://doi.org/10.21967/jbb.v4i1.180.

25. Mahmood, Z.; Zahra, S.; Iqbal, M. et al. Comparative study of natural and modified biomass of Sargassum sp. for removal of $\mathrm{Cd}^{2+}$ and $\mathrm{Zn}^{2+}$ from wastewater.Appl Water Sci 2017, 7,34693481.https://doi.org/10.1007/s13201-017-0624-3.

26. Jozefaciuk, G.; Bowanko, G. Effect of acid and alkali treatments on surface areas and adsorption energies of selected minerals. Clays and clay minerals 2002, 50, 771783.https://doi.org/10.1346/000986002762090308.

27. Zheng, C.; Ling, Z.; Xiaobai, Z.; Zhimin, F.; An, L.Treatment technologies fororganic wastewater. Water Treat. 2013, 11, 250-286.https://doi.org/10.5772/52665.

28. Sonal, S.; Prakash, P.; Mishra, B.K.; Nayak, G.C. Synthesis, characterisation and sorption studies of a Zr(IV) impregnated highly functionalised mesoporous activated carbons. RSC Adv. 2020, 10, 1378313798.https://doi.org/10.1039/C9RA10103A.

29. Wang, H.; Gao, B.; Wang, S.; Fang, J.; Xue, Y.; Yang, K.Removal of Pb (II), Cu(II), and Cd (II) from aqueous solutions by biochar derived from $\mathrm{KMnO}_{4}$ treatedhickory wood. Bioresour. Technol. 2015, 197, 356362.https://doi.org/10.1016/j.biortech.2015.08.132 
30. Milla, I.M.N.; Syahri, M.A.; Wahyuni, E.T.; Roto, R.; Siswanta, D. Modification of styrofoam waste as a low-cost adsorbent for removal of cadmium ion in aqueous solution. Orient. J. Phys. Sciences 2018, 3, $127-$ 142.

31. Argun, M.E.; Dursun, S. A new approach to modification of natural adsorbent for heavy metal adsorption. Bioresour. Technol. 2008, 99, 2516-2527. https://doi.org/10.1016/j.biortech.2007.04.037.

32. Saini, S.; Katnoria, J.K.; Kaur, I. A comparative study for removal of cadmium(II) ions using unmodified and NTA-modified Dendrocalamus strictus charcoal powder. J. Environ. Health Sci. Eng. 2019, 17, $259-272$. https://doi.org/10.1007/s40201-019-00345-2.

33. Salihi, U.; Kutty, S.R.M.; Isa, M.H; Olisa E.; Aminu, N. Adsorption of copper using modified and unmodified sugarcane bagasse. Int. J. Appl. Eng. Res. 2015, 10, 40434-40438.

34. Sabela, M.I.; Kunene, K.; Kanchi, S.; Xhakaza, N.M.; Bathinapatla, A.; Mdluli, P.; Sharma, D.; Bisetty, K. Removal of copper (II) from wastewater using green vegetable waste derived activated carbon:An approach to equilibrium and kinetic study. Arab. J. Chem. 2019, 12, 4331-4339. https://doi.org/10.1016/j.arabjc.2016.06.001.

35. Saed, U.A.; Jaleel, N.S.A. Adsorption of copper ions from aqueous solution using raw and modified can papyrus: experimental and kinetic study. Al-Nahrain Journal for Engineering Sciences 2017, 20, 744-750.

36. Ye, H.; Zhang, L.; Zhang, B.; Wu, G.; Du, D. Adsorptive removal of $\mathrm{Cu}(\mathrm{II})$ from aqueous solution using modified rice husk. Int. J. Eng. Res. Appl. 2012, 2, 855-863.

37. Ali, A.; Saeed, K.; Mabood, F. Removal of chromium (VI) from aqueous medium using chemically modified banana peels as efficient low-cost adsorbent. Alexandria Engineering Journal 2016, 55,2933-2942. https://doi.org/10.1016/j.aej.2016.05.011.

38. Adane, T.; Haile, D.; Dessie, A.; Abebe, Y.; Dagne, H. Response surface methodology as a statistical tool for optimization of removal of chromium(VI) from aqueous solution by Teff (Eragrostis teff) husk activated carbon. Appl. Water Sci. 2020, 10,37. https://doi.org/10.1007/s13201-019-1120-8.

39. Dehghani, M.H.; Sanaei, D.; Ali, I; Bhatnagar, A. Removal of chromium(VI) from aqueous solution using treated waste newspaper as a low-cost adsorbent: Kinetic modelling and isotherm studies. J. Mol. Liq. 2016, 215, 671-679. https://doi.org/10.1016/j.molliq.2015.12.057.

40. Al-Shahrani, H.; Alakhras, F.; Al-Abbad, E.; AL-Mazaideh, G.; Hosseini-Bandegharaei, A.; Ouerfelli, N. Sorption of Co(II) ions from aqueous solutions using chemically modified chitosan. Glob. NEST J. 2018, 20, 620-627. https://doi.org/10.30955/gnj.002804.

41. Parab, H.; Joshi, S.; Shenoy, N.; Lali, A.; Sarma, U.S.; Sudersanan, M. Esterified coir pith as an adsorbent for the removal of $\mathrm{Co}(\mathrm{II})$ from aqueous solution. Bioresour. Technol. 2008, 99, 2083-2086. https://doi.org/10.1016/j.biortech.2007.03.058.

42. Ranaweera, K.H.; Godakumbura, P.I.; Perera, B.A. Adsorptive removal of Co(II) in aqueous solutions using clearing nut seed powder. Heliyon 2020, 6, e03684. https://doi.org/10.1016/j.heliyon.2020.e03684.

43. Ratan, S.; Singh, I.; Sarkar, J.; Naik, R.M. The removal of nickel from waste water by modified coconut coir pith. Chem. Sci. 2016, 7, 136. https://doi.org/10.4172/2150-3494.1000136.

44. Samarghandi, M.R.; Azizian, S.; Siboni, M.S.; Jafari, S.J.; Rahimi, S. Removal of divalent nickel from aqueous solutions by adsorption onto modified holly sawdust: equilibrium and kinetics. Iran. J. Environ. Health. Sci. Eng. 2011, 8, 181-188.

45. Shah, J.; Kumar, S.; Sharma, S.; Sharma, R.; Sharma, R. Removal of nickel from aqueous solution by using low cost adsorbents: A Review. IJSEAS 2016, 2, 48-73.

46. Zhang, X.; Hao, Y.; Wang, X.; Chen, Z. Rapid removal of Zinc(II) from aqueous solutions using a mesoporous activated carbon prepared from agricultural waste. Materials (Basel) 2017, 10, 1002. https://dx.doi.org/10.3390\%2Fma10091002.

47. Rajczykowski, K.; Sałasińska, O.; Loska, K. Zinc removal from the aqueous solutions by the chemically modified biosorbents. Water Air Soil Pollut. 2018, 229, 6. https://doi.org/10.1007/s11270-017-3661-5.

48. Afroze, S.; Sen, T.K.;Ang, H.M. Adsorption removal of zinc (II) from aqueous phase by raw and base modified Eucalyptus sheathiana bark: Kinetics, mechanism and equilibrium study. Process Saf. Environ. Prot. 2016, 102, 336-352. https://doi.org/10.1016/j.psep.2016.04.009.

49. Salihi, I.U.; Kutty, S.R.M.; Isa, M.H.; Aminu, N. Zinc removal from aqueous solution using novel adsorbent MISCBA. Journal of Water, Sanitation and Hygiene for Development, 2016, 6, 377-388. https://doi.org/10.2166/washdev.2016.141.

50. Moyo, M.; Chikazaza, L.; Nyamunda B.C.; Guyo, U. Adsorption batch studies on the removal of Pb(II) using maize tassel based activated carbon. J. Chem. 2013. http://dx.doi.org/10.1155/2013/508934. 
51. Yousefi, T.; Mohsen, M.A.; Mahmudian, H.R.; Torab-Mostaeidi, M.; Moosavian, M.A.;Aghayan, H. Removal of $\mathrm{Pb}(\mathrm{II})$ by modified natural adsorbent; Thermodynamics and kinetics studies.J. Water Environ. Nanotechnol. 2018, 3, 265-272. https://dx.doi.org/10.22090/jwent.2018.03.007.

52. Belhadri, M.; Mokhtar, A.; Meziani, S.; Belkhadem, F.; Sassi, M.; Bengueddach, A. Novel low-cost adsorbent based on economically modified bentonite for lead(II) removal from aqueous solutions. Arab. J. Geosci. 2019, 12, 88. https://doi.org/10.1007/s12517-019-4232-4.

53. Asere, T.G.; Stevens, C.V.; Laing, G.D. Use of (modified) natural adsorbents for arsenic remediation: A review. Sci. Total Environ. 2019, 676, 706-720. https://doi.org/10.1016/j.scitotenv.2019.04.237.

54. Attari, M.; Bukhari, S.S.; Kazemian, H.; Rohani, S. A low-cost adsorbent from coal fly ash for mercury removal from industrial wastewater. J. Env. Chem. Eng. 2017, 5, 391-399. https://doi.org/10.1016/j.jece.2016.12.014.

55. Rodrigues, J.A.V.; Martins, L.R.; Furtado, L.M.; Xavier, A.L.P.; de Almeida, F.T.R.; Moreira, A.L.S.L.; Melo, T.M.S.; Gil, L.F.; Gurgel, L.V.A. Oxidized renewable materials for the removal of $\mathrm{Co}(\mathrm{II})$ and $\mathrm{Cu}(\mathrm{II})$ from aqueous solution using in batch and fixed-bed column adsorption. Adv. Polym. Technol. 2020. https://doi.org/10.1155/2020/8620431.

56. Schwantes, D.; Gonçalves, A.C.; Coelho, G.F.; Campagnolo,M.A.; Dragunski, D.C.; Tarley, C.R.T.; Miola, A.J.; Leismann, E.A.V. Chemical modifications of cassava peel as adsorbent material for metals ions from wastewater. J. Chem. 2016. https://doi.org/10.1155/2016/3694174.

57. Rashed, M.N.; Gad, A.A.; AbdEldaiem, A.M. Preparation of low-cost adsorbent from waste glass for the removal of heavy metals from polluted water. J. Ind. Environ. Chem. 2018, 2, 7-18.

58. Obayomi, K.S.; Bello, J.O.; Nnoruka, J.S.; Adediran, A.A.; Olajide, P.O. Development of low-cost bioadsorbent from agricultural waste composite for $\mathrm{Pb}(\mathrm{II})$ and $\mathrm{As}(\mathrm{III})$ sorption from aqueous solution. Cogent Eng. 2019, 6, 1687274. http://doi.org/10.1080/23311916.2019.1687274.

59. Mu, L.; Losch, M.; Yang, Q.; Ricker, R.; Losa, S.N.; Nerger, L. Arctic-wide sea icethickness estimates from combining satellite remote sensing data and a dynamicice-ocean model with data assimilation during the CryoSat-2 period. J. Geophys.Res. Oceans 2018, 123, 7763-7780.https://doi.org/10.1029/2018JC014316.

60. Shi, J.; Zhao, Z.; Zhou, J.; Sun, T.; Liang, Z. Enhanced adsorption of As (III) on chemically modified activated carbon fibers. Appl. Water Sci. 2019, 9.https://doi.org/10.1007/s13201-019-0919-7.

61. Olasehinde, E.F.; Adegunloye, A.V.; Adebayo, M.A.; Oshodi, A.A. Sequestrationof aqueous lead (II) using modified and unmodified red onion skin. Anal. Lett. 2018, 51, 27102732.https://doi.org/10.1080/00032719.2018.1448989.

62. Wang, X.; Cui, Y.; Peng, Q.; Fan, C.; Zhang, Z.; Zhang, X. Removal of Cd(II) and Cu(II) from Aqueous Solution by $\mathrm{Na}^{+}$- Modified Pisha Sandstone. Journal of Chemistry 2020. https://doi.org/10.1155/2020/2805479.

63. Zafar, S.; Khan, M.I.; Lashari, M.H. et al. Removal of copper ions from aqueous solution using NaOH-treated rice husk. Emergent Mater. 2020, 3, 857-870.https://doi.org/10.1007/s42247-020-00126-w.

64. Al-Jlil, S.A. Adsorption of cobalt ions from waste water on activated Saudi clays. Appl Water Sci 2017, 7, 383-391.https://doi.org/10.1007/s13201-014-0253-z.

65. El-Sadaawy, M.; Abdelwahab, O. Adsorptive removal of nickel from aqueous solutions by activated carbons from doum seed (Hyphaenethebaica) coat.Alexandria Engineering Journal 2014, 53, 399-408. https://doi.org/10.1016/j.aej.2014.03.014.

66. Giraldo, S.; Robles, I.; Ramirez, A. Mercury removal from wastewater using agroindustrial waste adsorbents. SN Appl. Sci. 2020, 2, 1029.https://doi.org/10.1007/s42452-020-2736-X. 